\title{
PROSES PEMBELAJARAN QUANTUM TEACHING DALAM BAHASA INGGRIS PADA KELAS CO-EDUCATION BERBASIS ADIL GENDER
}

\author{
Hermanto \\ Sekolah Tinggi Agama Islam Al-Gazali Soppeng, Indonesia \\ e-mail: herman_dian@yahoo.com
}

\begin{abstract}
Quantum as an interaction that converts energy into light. Quantum Teaching meaningful interactions that convert light into energy because all energy is life and diversity in the Teaching process and interdeterminisme contain. The purpose of the Quantum Teaching is to create an effective Teaching environment, creating a fun Teaching process, the brain's ability to adjust to what is needed by the brain, to help improve the life and career success and to help accelerate the Teaching. Errors in understanding the meaning of gender is one factor that led to opposition or difficult to accept gender analysis in solving problems of social injustice. In order to align with the substance of the discussion of the context of Teaching English, Quantum Teaching emphasizes the need of planningn of Teaching conditions (matched) with topic.
\end{abstract}

Kata Kunci: Quantum Teaching, Berbasis Adil Gender.

\section{Pendahuluan}

Sebagai sebuah manifestasi pendidikan merupakan Hak Asasi Manusia. Pendidikan yang tidak diskriminatif akan menguntungkan, baik bagi perempuan maupun laki-laki, yang pada akhirnya akan mempermudah terjadinya kesetaraan dalam hubungan antara perempuan dan laki-laki. Gender sebagaimana didefinisikan secara umum adalah pembedaan peran dan tanggung jawab antara perempuan dan laki-laki sebagai hasil konstruksi sosial budaya masyarakat . Tataran bias gender banyak terjadi dalam berbagai bidang, termasuk dalam bidang pendidikan. Misalnya peran gender terjadi dalam hal mengakses lembaga pendidikan yang menyebabkan rendahnya tingkat partisipasi perempuan.

Sebagai calon-calon guru yang nantinya akan menjalankan tugasnya dalam dunia pendidikan, tidak saja diperlukan kompetensi yang luas, namun diperlukan juga strategistrategi yang harus dikuasai oleh calon-calon guru nantinya, dalam menghadapi proses belajar mengajar di kelas nantinya dengan peserta didik terutama dalam pengajaran bahasa Inggris pada kelas co-education berbasis adil gender. Strategi belajar mengajar 
yang harus dikuasai oleh calon-calon guru tersebut mencakup seperti media pembelajaran, bagaimana seorang guru nantinya memanfaatkan media-media yang ada dalam proses pembelajaran, selanjutnya ada pendekatan pembelajaran, metode pembelajaran, keterampilan mengajar, dan yang terakhir ada yang namanya model pembelajaran.

Namun, kenyataan di lapangan tidak berbanding lurus dengan asumsi diatas. Harapan akan pembelajaran bahasa Inggris yang lebih aktif, inovatif, kreatif, efektif, dan dan bisa meningkatkan motivasi siswa ibarat jauh panggang dari api. Suasana pembelajaran yang lesu, stagnan, serta kurang menyenangkan menjadi pemandangan sehari-hari dalam pembelajaran bahasa khususnya bahasa Inggris baik di sekolah-sekolah negeri ataupun di sekolah-sekolah swasta. ${ }^{1}$ Padahal secara teoritis, pembelajaran bahasa Inggris memiliki empat orientasi keterampilan yang bisa dikatakan cukup berat, yaitu:

1. Orientasi Keterampilan Reading, yaitu belajar bahasa inggris untuk tujuan mampu membaca dengan baik, benar dan lancar.

2. Orientasi Keterampilan Speaking, yaitu belajar bahasa inggris untuk mampu berkomunikasi dengan baik dengan lawan bicara supaya terjadi hubungan yang lebih intensive melalui bahasa tersebut. Orientasi ini cenderung lebih diutamakan penguasaannya karena terindikasi bahwa seseorang yang mampu menggunakan bahasa lisan berarti dianggap menguasai bahasa tersebut.

3. Orientasi Keterampilan Writing, yaitu belajar bahasa inggris yang bertujuan untuk mampu menulis kata demi kata dalam bahasa Inggris yang bersinergi dengan kemampuan menyusun kalimat.

4. Orientasi Keterampilan listening, yaitu belajar bahasa Inggris untuk mampu memahami dan mendengarkan dengan baik apa yang disampaikan oleh lawan bicara supaya tidak terjadi mis-komunikasi atau kesalahpahaman. Orientasi ini, antara lain, terlihat dengan dibukanya beberapa lembaga kursus bahasa Inggris diberbagai tempat maupun daerah.

Dalam memacu pencapain orientasi-orientasi tersebut, maka diperlukan berbagai metode yang dapat memacu pembelajaran bahasa Inggris sehingga bisa menjadi suatu pembelajaran yang lebih aktif, inovatif, kreatif, efektif, dan menyenangkan. Kehadiran Quantum Teaching adalah ibarat pancaran air penyubur tanah di tengah padang sahara pembelajaran bahasa Inggris yang kering dan tandus. Namun, penerapan Quantum Teaching tidak akan berjalan dengan efektif dan efisien sebagai media pengantar materi pengajaran bila penerapannya tanpa didasari dengan pengetahuan yang memadai tentang

${ }^{1}$ Salah satu indikator adanya permasalahan dengan pembelajaran bahasa Inggris adalah untuk mempelajari bahasa ini, waktu yang diperlukan cenderung lama, dimana hal tersebut jarang didapatkan pada pembelajaran bahasa Inggris misalnya. Lihat Sardiman AM, Interaksi dan Motivasi Belajar Mengajar, (Cet. XI; Jakarta: Raja Grafindo Persada, 2004), h.14. 
metode itu. Bahkan, metode bisa saja akan menjadi penghambat jalannya proses pembelajaran jika aplikasinya tidak tepat.

\section{Konsep Quantum Teaching}

Quantum teaching pertama kali dikembangkan oleh Bobbi De Porter. Mulai dipraktekkan pada tahun 1992, dengan mengilhami rumus yang terkenal dalam fisika quantum yaitu masa kali kecepatan cahaya kuadrat sama dengan energi. Dengan rumus itulah mendefinisikan quantum sebagai interaksi yang mengubah energi menjadi cahaya. Pembelajaran quantum bermakna interaksi-interaksi yang mengubah energi menjadi cahaya karena semua energi adalah kehidupan dan dalam proses pembelajarannya mengandung keberagaman dan interdeterminisme. Dengan kata lain interaksi-interaksi yang dimaksud mengubah kemampuan dan bakat alamiah siswa menjadi cahaya yang akan bermanfaat bagi mereka sendiri dan bagi orang lain. ${ }^{2}$

Pembelajaran quantum adalah pembelajaran yang mampu menciptakan interaksi dan keaktifan siswa, sehingga kemampuan, bakat, dan potensi siswa dapat berkembang, yang pada akhirnya mampu meningkatkan prestasi belajar dengan menyingkirkan hambatan belajar melalui penggunaan cara dan alat yang tepat, sehingga siswa dapat belajar secara mudah. Pada proses pembelajaran quantum terjadi penyelarasan dan pemberdayaan komunitas belajar, sehingga guru dan siswa yang terlibat dalam proses pembelajaran sama- sama merasa senang dan saling bekerja sama untuk mencapai hasil yang maksimal.

Adapun tujuan dari pembelajaran quantum adalah Untuk menciptakan lingkungan belajar yang efektif, menciptakan proses belajar yang menyenangkan, menyesuaikan kemampuan otak dengan apa yang dibutuhkan oleh otak, untuk membantu meningkatkan keberhasilan hidup dan karir dan untuk membantu mempercepat dalam pembelajaran. Pembelajaran quantum berpangkal pada psikologi kognitif, dan bukan fisika quantum meskipun serba sedikit istilah dan konsep quantum dipakai, pembelajaran quantum juga bersifat humanistis dan lebih konstruktivistis. ${ }^{3}$

2 Bobby De Porter, Quantum Teaching, alih bahasa oleh Ary Nilandari, (Cet. XI; Bandung: Kaifa, 2003), h. 3.

\footnotetext{
${ }^{3}$ Bobby De Porter, Quantum Teaching, alih bahasa oleh Ary Nilandari, h. 5
} 


\section{Langkah-Langkah Secara Umum}

Langkah- langkah dalam penerapan metode pembelajaran quantum diurutkan menjadi : (a) Pengkondisian awal, (b) Penyusunan rancangan pembelajaran, (c) Pelaksanaan metode pembelajaran kuantum, dan (d) Evaluasi. ${ }^{4}$

a) Pengkondisian awal

Tahap ini dimaksudkan untuk menyiapkan mental siswa mengenai model pembelajaran quantum yang menuntut keterlibatan aktif siswa. Melalui pengkondisian awal akan memungkinkan dilaksanakannya proses pembelajaran yang lebih baik. Kegiatan yang dilakukan dalam pengkondisian awal meliputi: penumbuhan rasa percaya diri siswa, motivasi diri, menjalin hubungan, dan ketrampilan belajar.

b) Penyusunan rancangan pembelajaran

Tahap ini sama artinya dengan dengan tahap persiapan dalam pembelajaran biasa. Kegiatan yang dilakukan dalam tahap ini adalah penyiapan alat dan pendukung lainnya, penentuan kegiatan selama proses belajar mengajar, dan penyusunan evaluasi.

c) Pelaksanaan metode pembelajaran quantum

Tahap ini merupakan inti penerapan model pembelajaran quantum. Kegiatan dalam tahap ini meliputi: (1) penumbuhan minat, (2) pemberian pengalaman umum, (3) penamaan atau penyajian materi, (4) demonstrasi tentang pemerolehan pengetahuan oleh siswa, (5) pengulangan yang dilakukan oleh siswa, (6) perayaan atas usaha siswa.

d) Evaluasi

Evaluasi dilaksanakan terhadap proses dan produk untuk melihat keefektifan model pembelajaran yang digunakan.

\section{Co-Education Berbasis Adil Gender}

Co-education berarti pengajaran yang baik bagi anak laki-laki dan perempuan di sekolah yang sama dan di bawah atap yang sama. Ini juga berarti menanamkan pendidikan yang sama untuk kedua jenis kelamin tanpa ada perbedaan. Sistem pendidikan bertujuan untuk membawa anak laki-laki dan perempuan bersama-sama. Hal ini memungkinkan pencampuran bebas dari jenis kelamin tanpa hambatan apapun.

Filsuf Yunani, Plato telah disebarkan sistem co-education di zaman kuno. Dia percaya bahwa co-education akan menciptakan perasaan persahabatan antara laki-laki dan perempuan. ${ }^{5}$ Plato adalah pendukung besar pendidikan bagi perempuan. Oleh karena itu, ia ingin mereka dididik dengan laki-laki di lembaga yang sama. Dia merasa bahwa

\footnotetext{
${ }^{4}$ Bobby De Porter, Quantum Teaching, alih bahasa oleh Ary Nilandari, h. 8.

${ }^{5}$ DePorter, Bobby dan Mike Hernacki, Quantum Teaching: Unleashing the Genius in You, diterjemahkan oleh Alwiyah Abdurrahman, Quantum Teaching: Membiasakan Belajar Nyaman dan Menyenangkan, (Cet. XXV; Bandung: Kaifa, 2007), h. 10.
} 
jika pria dan wanita diajarkan bersama-sama, itu akan mengembangkan kepribadian mereka secara maksimal. Mereka tidak akan merasa malu dari satu sama lain. Ia menganjurkan bahwa itu adalah satu-satunya metode dimana keduanya bisa menjadi anggota masyarakat yang berguna tersebut.

Plato dalam kenyataannya banyak dipengaruhi oleh sistem co-education di Sparta, sebuah kota di Yunani. Anak laki-laki dan perempuan diberi pendidikan akademik dan fisik bersama-sama. Anak perempuan dan anak laki-laki belajar dan bermain bersama. Mereka berdua mengajarkan seni pertempuran, berkuda, panahan dll. Jadi para wanita Sparta tidak lebih rendah dari pria. ${ }^{6}$

\section{Keuntungan dari Co-education:}

Ada banyak keuntungan dan hampir tidak ada kelemahan dalam sistem coeducation pendidikan. Keuntungan pertama adalah bahwa jika anak laki-laki dan perempuan diajarkan bersama-sama, tidak akan ada kebutuhan untuk membuka sekolahsekolah yang terpisah untuk anak laki-laki dan perempuan. Co-education adalah sistem yang sangat adil, karena kedua anak laki-laki dan perempuan dapat belajar di sekolah yang sama.

Kedua, anak-anak harus hidup bersama dalam masyarakat dalam kehidupan mereka kemudian dan jika mereka diajarkan bersama-sama dari awal, mereka bisa saling memahami satu sama lain dengan baik. Gadis-gadis tidak akan merasa malu di hadapan anak-anak. Anak-anak juga tidak akan menggoda anak perempuan. Mereka diajarkan bersama-sama, itu akan menciptakan rasa persaingan yang sehat di antara mereka. Dengan cara ini, mereka akan bekerja keras dan memberikan perhatian serius terhadap studi mereka. Perasaan persahabatan juga akan mengembangkan antara anak laki-laki dan perempuan. Dengan demikian mereka akan memiliki perkembangan yang seimbang dari kepribadian mereka.

\section{Pengertian Dan Konsep Dasar Gender}

Masih banyak orang yang belum bisa membedakan secara jelas antara pengertian istilah jenis kelamin dan gender, sehingga tidak jarang kedua terminologi tersebut dianggap sama secara konseptual. Anggapan ini tentu tidak tepat, sebab istilah jenis

${ }^{6}$ DePorter, Bobby dan Mike Hernacki, Quantum Teaching: Unleashing the Genius in You, diterjemahkan oleh Alwiyah Abdurrahman, Quantum Teaching: Membiasakan Belajar Nyaman dan Menyenangkan, h. 15. 
kelamin dan gender memiliki pengertian yang sama sekali berbeda. Oleh karena itu, dalam kajian gender hal penting yang perlu dilakukan sebelum membahas lebih lanjut adalah memahami terlebih dahulu perbedaan konsep gender dan seks (jenis kelamin). Kesalahan dalam memahami makna gender merupakan salah satu faktor yang menyebabkan sikap menentang atau sulit bisa menerima analisis gender dalam memecahkan masalah ketidakadilan sosial. ${ }^{7}$

Secara terminologis, makna jenis kelamin (sex) adalah perbedaan fisik yang didasarkan pada anatomi biologi manusia, terutama yang berhubungan dengan fungsi reproduksi. Berdasarkan perbedaan fisik dan biologis inilah dapat teridentifikasi dua jenis kelamin manusia, yaitu laki-laki dan perempuan. Dengan kata lain, perbedaan antara perempuan dan laki-laki murni didasarkan pada fungsi organ reproduksi yang kodrati dan bersifat alamiah (nature). Karena didasarkan pada perbedaan yang bersifat alamiah, perbedaan jenis kelamin berlaku secara universial bagi semua perempuan dan laki-laki di dunia. ${ }^{8}$

Sedangkan gender adalah pembedaan peran, fungsi dan tanggung jawab antara perempuan dan laki-laki yang dihasilkan dari konstruksi sosial budaya dan dapat berubah sesuai dengan perkembangan zaman. Secara etimologis gender berasal dari kata gender yang berarti jenis kelamin. Oleh karena itu gender dapat berubah dari tempat ketempat, waktu ke waktu, bahkan antar kelas sosial ekonomi masyarakat. Mufidah dalam Paradigma Gender mengungkapkan bahwa pembentukan gender ditentukan oleh sejumlah faktor yang ikut membentuk, kemudian disosialisasikan, diperkuat, bahkan dikonstruksi melalui sosial atau kultural, dilanggengkan oleh interpretasi agama dan mitos-mitos seolah-olah telah menjadi kodrat laki-laki dan perempuan. ${ }^{9}$

Gender merupakan analisis yang digunakan dalam menempatkan posisi setara antara laki-laki dan perempuan untuk mewujudkan tatanan masyarakat sosial yang lebih egaliter. Jadi, gender bisa dikategorikan sebagai perangkat operasional dalam melakukan measure (pengukuran) terhadap persoalan laki-laki dan perempuan terutama yang terkait dengan pembagian peran dalam masyarakat yang dikonstruksi oleh masyarakat itu sendiri. Hanya saja, yang dianggap mengalami posisi ter-marginalkan sekarang adalah

\footnotetext{
${ }^{7}$ Gordon Dryden, Revolusi Cara Belajar, (Cet. VIII; Bandung: Kaifa, 2004), h. 327.

${ }^{8}$ Mansour Faqih, Analisis gender dan Transformasi Sosial, (Yogyakarta : Pustaka Pelajar, 1996), h. 15 .

${ }^{9}$ Lips, H.M, Sex and gender: An introduction, (London: Mayfield Publishing Company, 1993), h. 18.
} 
pihak perempuan, maka perempuanlah yang lebih ditonjolkan dalam pembahasan untuk mengejar kesetaraan gender yang telah diraih oleh laki-laki beberapa tingkat dalam peran sosial, terutama di bidang pendidikan karena bidang inilah diharapkan dapat mendorong perubahan kerangka berpikir, bertindak, dan berperan dalam berbagai segmen kehidupan sosial.

\section{Kesetaraan Gender Dalam Pendidikan}

Keadilan dan kesetaraan adalah gagasan dasar, tujuan dan misi utama peradaban manusia untuk mencapai kesejahteraan, membangun keharmonisan kehidupan bermasyarakat, bernegara dan membangun keluarga berkualitas. Kesetaraan gender adalah kesamaan kondisi bagi laki-laki dan perempuan untuk memperoleh kesempatan serta hak-haknya sebagai manusia, baik dalam kegiatan politik, hukum, ekonomi, sosial budaya, pendidikan dan pertahanan dan keamanan nasional serta kesamaan dalam menikmati hasil pembangunan. Perbedaan biologis tidak bisa dijadikan dasar untuk terjadinya diskriminasi mengenai hak sosial, budaya, hukum dan politik terhadap satu jenis kelamin tertentu. $^{10}$

Dalam memenuhi kesetaraan dan keadilan gender diatas, maka pendidikan perlu memenuhi dasar pendidikan yakni menghantarkan setiap individu atau rakyat mendapatkan pendidikan sehingga bisa disebut pendidikan kerakyatan. Ciri-ciri kesetaraan gender dalam pendidikan adalah sebagai berikut: ${ }^{11}$

1. Perlakuan dan kesempatan yang sama dalam pendidikan pada setiap jenis kelamin dan tingkat ekonomi, sosial, politik, agama dan lokasi geografis publik.

2. Adanya pemerataan pendidikan yang tidak mengalami bias gender.

3. Memberikan mata pelajaran yang sesuai dengan bakat dan minat setiap individu.

4. Pendidikan harus menyentuh kebutuhan dan relevan dengan tuntutan zaman.

5. Individu dalam pendidikannya juga diarahkan agar mendapatkan kualitas sesuai dengan taraf kemampuan dan minatnya.

\section{Penerapan Quantum Teaching dalam Pengajaran Bahasa Inggris pada Kelas Co-Education Berbasis Adil Gender}

Kehadiran quantum teaching telah memberikan angin segar dalam dunia pendidikan, termasuk pembelajaran termasuk bahasa Inggris. Kehadiran quantum teaching diharapkan mampu untuk membangunkan pembelajaran bahasa Inggris dari kelesuan metode pembelajaran yang stagnan dalam mengikuti pembelajaran bahasa asing yang terus bergerak dinamis mengiringi perputaran masa.

\footnotetext{
${ }^{10}$ Mufidah Ch, Bingkai Sosial Gender: Islam, Strukturasi dan Konstruksi Sosial, h. 29.

${ }^{11}$ Mansour Faqih, Analisis gender dan Transformasi Sosial, h. 30.
} 
Sebagai acuan dalam pembahasan tentang penerapan quantum teaching dalam mewujudkan pembelajaran bahasa Inggris yang aktif, inovatif, kreatif, efektif, dan menyenangkan, jika dikutip apa yang disampaikan oleh Djoko Saryono dimana ia mengungkapkan poin-poin tentang bagaimana pembelajaran dan para siswa diarahkan pada suatu simponi orkestra pembelajaran quantum sebagai berikut: ${ }^{12}$

a. Pembelajaran berlangsung secara aktif jika siswa itu aktif dan kreatif. Bukti keaktifan dan kekreatifan itu dapat ditemukan pada fungsi otak kanan dan kiri siswa. Pembelajaran pasif cenderung mengingkari kenyataan bahwa siswa itu aktif dan kreatif sebagaimana mengingkari fungsi otak kiri dan kanan.

b. Pembelajaran berlangsung efektif dan optimal bila didasarkan pada gaya belajar siswa. Setidak-tidaknya ada tiga gaya belajar yang harus diperhitungkan dalam proses pembelajaran, yaitu gaya auditoris, gaya visual, dan gaya kinestesis.

c. Pembelajaran berlangsung efektif dan optimal bila tercipta suasana nyaman, menyenangkan, rileks, sehat, dan menggairahkan sehingga kenyamanan, kesenangan, kerileksan, dan kegairahan dalam pembelajaran perlu diciptakan dan dijaga.

d. Pembelajaran melibatkan lingkungan fisikal-mental dan kemampuan pikiran atau potensi diri siswa secara serempak. Oleh karena itu, penciptaan dan pemeliharaan lingkungan yang tepat sangat penting.

e. Pembelajaran membutuhkan keserasian konteks dan isi. Semua konteks pembelajaran perlu dikembangkan secara serasi dengan isi pembelajaran.

f. Pembelajaran berlangsung optimal apabila terdapat keragaman dan kebebasan. Oleh karena itu, keragaman dan kebebasan perlu diakui, dihargai, dan diakomodasi dalam proses pembelajaran. ${ }^{13}$

Dalam proses pembelajaran bahasa Inggris dengan menggunakan quantum teaching, seorang guru harus meneliti karakteristik belajar para siswanya apakah termasuk pelajar visual, auditorial, ataukah kinestetik. Hal tersebut akan membantu guru dalam mencurahkan diri pada modalitas belajar terbaik mereka. ${ }^{14}$ Contoh sederhana yang bisa diambil adalah dalam pembelajaran materi bahasa Inggris Speaking, seorang siswa yang memiliki karakteristik belajar visual, dapat diajarkan Speaking dengan menggunakan media gambar sebagai penguatan (reinforcement) akan bacaan yang ditransfer secara oral.

Dalam rangka menyelaraskan konteks dengan substansi pembahasan pembelajaran bahasa Inggris, quantum teaching menegaskan perlunya panataan kondisi

12 Sardiman AM, Interaksi dan Motivasi Belajar Mengajar, (Cet. XI; Jakarta: Raja Grafindo Persada, 2004), h. 14.

${ }^{13}$ Djoko Saryono, Pembelajaran Quantum sebagai Model Pembelajaran yang Menyenangkan, http://www.microsoft.com. (06 Oktober 2017)

${ }^{14}$ Bobby De Porter, Quantum Teaching, alih bahasa oleh Ary Nilandari, h. 117. 
pembelajaran yang sejalan (matched) dengan topik bahasan. Suatu hal yang harus dipertegas disini adalah kesesuaian disini bukan hanya sebatas kesesuaian pada kondisi ruangan yang ukurannya hanya sekitar 10 x 10 materi, tapi mencakup konteks yang lebih luas dari pada itu yaitu konteks sosio-kultural dimana mereka akan menggunakan bahasa Inggris tersebut.

\section{Simpulan}

Berdasarkan pembahasan diatas, dapat ditarik beberapa kesimpulan bahwa Quantum Teaching adalah seperangkat metode dan falsafah belajar yang telah terbukti mampu melejitkan potensi belajar para siswa dengan melakukan penggabunganpenggabungan teori-teori pembelajaran seperti suggestology, teori otak kanan/kiri, pilihan modalitas (visual, auditorial, dan kinestetik), teori kecerdasan ganda, teori kecerdasan ganda, pendidikan holistik, belajar berdasarkan pengalaman, belajar dengan simbol (metaphoric Teaching), serta simulasi/permainan. Co-education berarti pengajaran yang baik bagi anak laki-laki dan perempuan di sekolah yang sama dan di bawah atap yang sama. Kesetaraan gender adalah kesamaan kondisi bagi laki-laki dan perempuan untuk memperoleh kesempatan serta hak-haknya sebagai manusia, agar mampu berperan dan berpartisipasi dalam kegiatan politik, hukum, ekonomi, sosial budaya, pendidikan dan pertahanan dan keamanan nasional (hankamnas) serta kesamaan dalam menikmati hasil pembangunan. Keadilan gender adalah suatu perlakuan adil terhadap perempuan dan laki-laki. Perbedaan biologis tidak bisa dijadikan dasar untuk terjadinya diskriminasi mengenai hak sosial, budaya, hukum dan politik terhadap satu jenis kelamin tertentu. Pembelajaran bahasa Inggris harus diaplikasikan sebagai suatu proses pembelajaran yang aktif, inovatif, kreatif, efektif dan menyenangkan untuk mengatasi kelesuan pembelajaran bahasa Inggris selama ini. Quantum Teaching mengasumsikan bahwa proses pembelajaran seperti sebuah orkestra yang tergabung dari beberapa komponen tapi mampu menghasilkan alunan nada yang menghibur bukan hanya mereka yang tergabung dalam orkestra tersebut tapi termasuk mereka yang ada di sekitarnya. 


\section{Referensi}

Amasari (Member of PSG LAIN), Laporan Penelitian Pendidikan Berdasarkan Gender, Banjarmasin: IAIN Antasari, 2005.

Colin Rose, dalam Dave Maier, Accelerated Teaching. Cet.I; Bandung: Kaifa; 2001.

DePorter., Bobby dan Mike Hernacki, Quantum Teaching: Unleashing the Genius in You, diterjemahkan oleh Alwiyah Abdurrahman, Quantum Teaching: Membiasakan Belajar Nyaman dan Menyenangkan, Cet. XXV; Bandung: Kaifa, 2007.

De Porter, Bobby, Quantum Teaching, alih bahasa oleh Ary Nilandari. Cet. XI; Bandung: Kaifa. 2003.

DePorter., Bobby dkk., Quantum Teaching: Orchestrating Student Success, diterjemahkan oleh Ary Nilandari, Quantum Teaching: Mempraktikkan Quantum Teaching di Ruang-Ruang Kelas, Cet. XI; Bandung: Kaifa, 2003.

Fakih, M, Analisis gender dan transformasi sosial, Yogyakarta: Pustaka Pelajar, 2003.

Guruvalah, Quantum Teaching Melejitkan Potensi Anda, dikutip dari Artikel Majalah Sang Surya, Samarinda Kalimantan Timur, http://www.geocities.com. 06 Oktober 2017.

Gordon Dryden, Revolusi Cara Belajar, Cet. VIII; Bandung: Kaifa, 2004).

Hanun Asrohah, Sosiologi Pendidikan, Surabaya: Kopertais Press, 2008.

Jhon M. Echol, dan Hasan Shadily, Kamus Besar Inggris-Indonesia, Jakarta : Gramedia Pustaka Utama, 1996.

Kurnia., Saptiawan Santana, Quantum Teaching bagi Pendidikan Jurnalistik: (Studi pembelajaran jurnalistik yang berorientasi pada life skill), http://akhmadsudrajat.wordpress.com. 06 Oktober 2017.

Lips, H.M, Sex and gender: An introduction, London: Mayfield Publishing Company, 1993.

Mansour Faqih, Analisis gender dan Transformasi Sosial, Yogyakarta: Pustaka Pelajar, 1996.

Mufidah Ch, Bingkai Sosial Gender: Islam, Strukturasi dan Konstruksi Sosial. Malang: UIN Maliki Press, 2010.

Prent, K, Adisubrata, J., \& Poerwadarminta, W.J.S, Kamus Latin Indonesia, Yogyakarta: Kanisius diterbitkan). Jakarta: Dirjen Kelautan, Pesisir, Dan Pulau-Pulau Kecil DKP, 1969.

Rostikawati, R. Teti, Mind Mapping dalam Metode Quantum Teaching dan Pengaruhnya terhadap Prestasi Belajar dan Kreatifitas Siswa, http://pkab.wordpress.com .06 Oktober 2017.

Ramadhan, A. Tarmizi, Pembelajaran Aktif, Inovatif, Kreatif, Efektif, dan Menyenangkan, http://tarmizi.wordpress.com. 06 Oktober 2017. 
Ekspose Volume 16, Nomor 2, Juli - Desember 2017 P-ISSN: 1412-2715, E-ISSN: 2616-4412

Saryono, Djoko, Pembelajaran Quantum sebagai Model Pembelajaran yang Menyenangkan, http://www.microsoft.com. 06 Oktober 2011.

Sardiman AM, Interaksi dan Motivasi Belajar Mengajar, Cet. XI; Jakarta: Raja Grafindo Persada, 2004. 